\title{
THE UNSOLVED PROBLEM OF TRAFFIC ACCIDENTS WORLDWIDE
}

Agim NUHIU, PhD*

Ajten RAMADANI, PhD**

*Ministry of the Interior, Republic of North Macedonia, agimnuhiu@hotmail.com

**Correspondent Author: Ministry of the Interior, Republic of North Macedonia, ajtenramadani@gmail.com

\begin{tabular}{ll}
\hline $\begin{array}{l}\text { Article history: } \\
\text { Accepted } 01 \text { August } 2019 \\
\text { Available online } 19 \text { November } 2019\end{array}$ & $\begin{array}{l}\text { The problem of traffic accidents is not generally discussed as an issue with any political, } \\
\text { philosophical, psychological, or cultural implications. What might such implications be? In terms of }\end{array}$ \\
$\begin{array}{l}\text { Keywords: } \\
\text { Traffic }\end{array}$ & policing, countries and nations worldwide generally have quite a narrow focus on prophylaxis (road \\
Accidents & safety education, awareness campaigns, warning signs about speed limits, dangerous corners, etc.) \\
Policing & and punishment (fines, trials, sometimes prison sentences for those who cause accidents). This paper \\
$\begin{array}{l}\text { Democracy } \\
\text { Liberty }\end{array}$ & argues that a broader and deeper analysis of the issue is needed, in order to understand (principally) \\
Culture & and possibly pre-empt or at least remediate (secondarily) the harm and damage of traffic accidents. \\
civilization & Methodology: systemic analysis and culture-critical analysis combined with perspectives from \\
& public policy, philosophy, democratic and libertarian political theory, and psychology. Conclusions \\
& will promote improved clarity and refreshed thinking about this important but misunderstood issue \\
& on the part of researchers and practitioners alike.
\end{tabular}

\section{Introduction}

In 2015 the United Nations promulgated its seventeen Sustainable Development Goals (SDGs). Goal number 3, which is headed 'Good Health and Well-Being', includes a 'Target 3.6', as follows: "By 2020, halve the number of global deaths and injuries from road traffic accidents." (United Nations 2015) At the time of writing, 2020 is two months away. How is the world progressing in its pursuit of SDG Target 3.6?

In a word, badly. The report from the World Health Organization (WHO) titled 'Global status report on road safety 2018', published on 7 December 2018, concludes its 'Summary of progress to date' with these words:

The number of road traffic deaths continues to climb, reaching 1.35 million in 2016, while the rate of death relative to the size of the world's population has stabilized in recent years. The progress that has been achieved has not occurred at a pace fast enough to compensate for the rising population and rapid motorization of transport taking place in many parts of the world.
At this rate, the SDG target 3.6 to halve road traffic deaths by 2020 will not be met. (WHO 2018a, 94)

In addition to the 1.35 million annual death-rate, over 50 million people suffer serious injury from car crash events worldwide every year, according to the same WHO report. The growth-rate of road traffic deaths and injuries is constant, in line with population growth. It is reasonable, based on these data, to conclude that the problem remains unsolved.

But is it ultimately and definitively unsolvable? What if it is not? And how would we know whether it is or not? Is there a logic and a pragmatics to this issue which might allow us to venture a more dynamic answer other than merely "Wait and see" or "Only time will tell"? Because if we can reason our way to a fuller understanding of all its roots, branches and implications, we ought to be much better able to achieve pre-emption and remediation, as is assumed by all involved to be the goal. Hence, this paper sets out to answer these questions using rational analysis, logic, and critical philosophical reasoning.

\section{Efforts to Reduce Car Crash Events}


There have been massive efforts, stretching far back in time, almost all the way back to the first appearance of motor vehicles equipped with fossil-fuel-powered internal combustion engines in significant numbers on roads, to address the problem of traffic accidents in the world.

There were three countries where the mass motorization of society first got going: Germany, France, and Great Britain. The USA was not far behind. In Germany, prior to 1900 , there were only individual German States' efforts to manage the problems of road accident events. (Niemann \& Hermann 2006) The consistent and concerted efforts in Imperial Germany to legislate, regulate, police and educate motor vehicle users - which continued through two world wars, the 'two Germanies' era during the Cold War, the Great Reunification and right up to the present day - began 113 years ago in 1906 with the Polizei-Verordnung über den Verkehr mit Kraftfahrzeugen. (Fack 2000, 167) In Britain, the UK's Royal Society for the Prevention of Accidents (RoSPA) was founded in 1916, at a time when there were only about 100,000 cars in the country, whereas today there are over 37.9 million licensed vehicles in Great Britain. (GOV.UK. 2018) The RoSPA has been running campaigns to prevent or reduce road accidents for over a hundred years, non-stop. In France, another pioneer country in the development of automobiles, the laws and campaigns for road safety pre-dated the automobile itself. (Government of France 2019) France is the most extreme case. In France, there are more than twenty different bodies - "Organismes intervenant sur la sécurité routière" - dedicated to stopping the road traffic carnage. These bodies, and those in Germany and the UK, have all been working hard for well over 100 years to solve the problem, yet the problem has everywhere only grown bigger. This is a strange outcome.

A full and exhaustive list of all the present-day groups, bodies, campaigns and conferences for cutting the road accident statistics would be far too long to include here, because apart from the UN's various bodies and other transnational agencies such as the European Transport Safety Council (ETSC) in the EU, almost every country has its own NGO or charitable foundation or government agency dedicated to preventing car crashes.

Just to mention at random a few examples:

1. The Road Traffic Injury Research Network (RTIRN) is an international body founded in 1999 and based at Makerere University in Kampala, Uganda; the RTIRN focuses its efforts on investigating traffic accidents in developing countries, nowadays more commonly referred to as LICs or LMICs, low and middle income countries. (World Bank Data Team 2019) All the evidence shows that there are more deaths and injuries in LMICs than in the affluent member states of the OECD. (Nantulya \& Reich 2002) As the WHO's "Road Safety Factsheet" states, "The risk of dying in a road traffic crash is more than 3 times higher in lowincome countries than in high-income countries. (WHO 2018b)

2. The Australasian College of Road Safety (ACRS), founded in 1988, acts as "the peak regional body [in Australia and New Zealand] for road safety professionals, advocates, and members of the public who are focused on saving lives and serious injuries on our roads". As such, it works to support the Canberra government's long-established National Road Safety Strategy 2011-2020, and the UN's Decade of Action for Road Safety 2011-2020. (ACRS 2019) (Australian Federal Government Transport and Infrastructure Council 2019) (WHO 2010)

3. Interestingly, and somewhat curiously, the WHO's main page on the United Nations Road Safety Collaboration presently (August 2019) contains a link to a now-defunct website called "www.decadeofaction.org". This link yields a redirect to a branch of none other than the FIA website. The FIA is the Fédération Internationale de l'Automobile, the motor vehicle industry's global advocacy and promotional body, whose sub-branch, the FIA Foundation, is a charity dedicated to road safety. The FIAF describes itself as undertaking "[...] research into public policy issues relating to the automobile's interaction with society". So, even the world's carmakers are investing in efforts to reduce car-crash deaths and injuries. (UNRSC 2019) (FIAF 2019)

This move is logical enough. After all, if a company's product is causing 1.35 million deaths and 50 million injuries every year, it would be only sensible for that company to make a public relations effort to appear concerned. But why would the UN let its high-minded 'decade of action' be linked to the FIA, an agent of commerce? From the UN's standpoint, however, this is not so strange. Where the mitigation of traffic accidents is concerned, all comers are welcome at the table, and vehicle manufacturers are certainly interested in showing that they are working constantly to make their products safer.

In view of all the massive worldwide efforts mentioned above, and so many others too numerous even to mention here, why has nothing been achieved? This is an evident puzzle, and a mystery: 
there has to be some better explanation than just to shrug and say, "Well, we tried our best, but the problem is bigger than our available resources could deal with." The implication of this excuse is clearly, "Let us throw even more money at the problem."

What is it about the problem of car crashes that makes it so intractably difficult - or indeed, apparently impossible - to solve? Is there perchance some unconscious, undisclosed or unacknowledged element deep in the human psyche or inherent in the culture of the automobile age that blocks or defies all treatment? What is the logic, what is the psychology, of car crashes?

\section{The Car Crash Mystery: Two Lines of Reasoning}

Let us now seek to shine some light on the problem by analyzing the political issues behind it and the psychocultural dimensions around it. The political issues connect it with a particular understanding of democracy, individual liberty, and the sempiternal tension between the individual and the collective or, as it increasingly presents itself in the modern age, the 'system'. The psychological and cultural analysis pertains to a certain theory of 'civilization' itself, best represented in the works of Freud and his successors. Usefully, these two lines of thought are convergent in the case of the car crash problem.

\subsection{Freudian Theory of Civilization}

The argument presented in this paper starts with a psychocultural critique because politics and laws and rights and freedoms and societal institutions like a parliament or a police force arise upon the foundation of culture, which has its basis in the structure of the human psyche, not the other way around. The answer to the conundrum of car-crash prevalence and intractability can partially be found by relating this conundrum to the seminal essay by Sigmund Freud, 'Civilization and its discontents' (Das Unbehagen in der Kultur, 1930).

Let us sum up, briefly, the picture painted in Das Unbehagen in der Kultur. Civilized behavior is merely an epiphenomenon of the unconscious, both the individual and the collective unconscious, in their privileged co-determining relation to each other. Civilized norms arise only as the resultant or product of repression of the destructive urges, drives, instincts and desires which inhabit and power the unconscious mind. The instance or mechanism of this repression is like a moral conscience - again, both individual and collective, with both of these dimensions crucially codetermining each other.
Freud's key insight is that this repression is never strong enough to hold out for very long against the underlying - and more powerful - forces of violence and destructiveness in the unconscious. There is always going to be the proverbial 'return of the repressed'. Hence, civilization itself is perpetually fragile, and destined inevitably to break down sooner or later, as seen in minor and major destructive outbreaks of violent 'uncivilized' behavior such as the Great War.

What has all this got to do with the intractability of car crash fatalities and injuries? It would seem evident enough that the whole vast global apparatus of car-accident prevention corresponds to the mechanism of censorship and repression in Freud's model. In this regard, it resembles certain strictures of religious discourses such as the Judaeo-Christian 'Thou shalt not kill', a 'commandment' which, in more than two millennia, has never proved effectual in the least. Just like all the preaching in the last 120 years about 'Thou shalt not crash thy car', such preaching was always doomed to fail in its pious wish to repress destructive and self-destructive tendencies - including Freud's other discovery, which is also quite relevant in the present context, that of the unconscious death-wish, a concept first defined in an earlier work of Freud's, Beyond the Pleasure Principle (German: Jenseits des Lustprinzips, 1920).

\subsubsection{Counter-arguments}

A possible counter-argument is that car crashes do not happen as a result of any will to do damage: they are, precisely, 'accidents', which nobody actually intended to cause, and therefore Freud's model does not fit them. The answer to this objection is that the human individual or collective will is a conscious entity, not part of the unconscious mind, and therefore the model does not require the presence or action of any conscious will-to-crash in order to be applicable.

It may be objected that the statistics on vehicular traffic accidents would likely be much worse if there had not been all this quixotic effort to curb them, and therefore it is not a case of the failure of repression to prevent destructive behavior: rather, it is a case of commendable partial success. The answer to this objection is that it belongs in the realm of pure untested speculation: we have only the results that we actually have, and not other, imaginary results. What would or could or might have happened in the absence of all these repressive measures remains unknown.

\subsection{The politics of Car Crashes}

In a world where state encroachment on individual liberties is self-evidently rampant, it can be argued that such liberties urgently require to be protected and defended. In a world where inequality of wealth and of individual rights is worse than ever 
and constantly worsening further, it can be argued that any effort to make people more equal must be welcomed, encouraged and supported. At the same time, it seems fairly clear that State power over the individual has increased in this century out of all proportion, whereby the great paradox is that the more powerful the State becomes, the less able it is to solve the large problems of the world we all live in, such as global warming, climate change, species extinction, deforestation and desertification, environmental collapse, and - yes, indeed - world poverty. In such an alarming, dire and threatening context, what can be said or done politically about the topic under discussion here, cars and car crashes?

Not every country in the world is democratic: far from it. Also, the levels of 'democraticness' in the world are becoming less and less. Freedom House, which measures such levels, concludes in its 2019 report that:

Freedom in the World has recorded global declines in political rights and civil liberties for an alarming 13 consecutive years, from 2005 to 2018 . The global average score has declined each year, and countries with net score declines have consistently outnumbered those with net improvements. (Freedom House 2019)

However, for the purposes of this paper, the discussion will focus on the ideal model of democracy, which still to a greater or lesser degree is instantiated in many countries. In a representative or parliamentary system of democracy, the State is supposed to serve the interests of 'the people', and be accountable to them. The State is the collective, it is the 'people' but attired in the garb and trappings of power. However, the relation between any given individual and his/her collective is never harmonious, because it is never a one-to-one relation. The individual and the collective are almost always in conflict with each other, generally to the harm and detriment of the former. The relationship is not symmetrical, since the Collective, acting through the agency of its State apparatuses, always constrains and coerces the Individual, whereas the Individual is less and less able to constrain or coerce the Collective, through traditional means such as voting, petitioning, lobbying, protesting, demonstrating, and indeed even revolution. It can scarcely be argued that this situation is a good thing: it is simply an inevitability. Short of a worldwide dystopian disintegration of the social fabric and its established machinery of social order, which anarchists have imagined but which few others desire, nothing can arrest or reverse the onward march of State power over the citizen.

On the positive side of the individual liberty balance sheet, the advent of 'automobilism' (from Automobilismus, as the Germans call it) has been hailed as a great leap forward for individual freedom, and this is most assuredly the case. In the United States, libertarian thinkers like Randal O'Toole have made this case most plausibly:

... [private car] mobility is really important because mobility gives people access to more economic resources, more social resources, more recreation opportunities. Mobility of course has completely transformed in the 20th century. Before 1800 , hardly anybody in the world had ever traveled faster than a horse could run and lived to tell about it. (O'Toole 2019)

According to Spencerian Libertarianism, individual freedom understood as the right to maximum and equal but negative liberty - is the highest value. By 'negative' liberty, the followers of Herbert Spencer mean 'the absence of forcible interference from other agents'. (Narveson 1988) If one can afford to own and run a car, one can certainly gain a large measure of such freedom, even today: one can drive around all over the map quite freely as long as one pays one's car registration and insurance, and abides by certain simple 'rules of the road'. Up to now, Spencer's proverbial 'other agents' did not substantially interfere with this liberty. Now, however, the rising hyper-dominance of State power in our de-democratizing world order threatens this individual right.

Few would argue that individual freedom should include the right to crash one's car and hurt or kill another individual, and certainly no genuine libertarian would espouse such a view, which would contradict the principle of equal negative liberty. However, the history of the ever more pervasive and intrusive road safety campaigns, laws, and regulations, accompanied by the mass deployment of high surveillance technologies, would suggest that things are moving inexorably in the direction of greater restrictions on citizens. This inexorable progression looks like culminating ultimately - but in a relatively near future - in the conquest of the roads by autonomous vehicles, or 'self-driving cars'. Opinions diverge widely on the foreseeable timeline for this to happen.

\subsection{Self-driving Cars}

Some of the prominent advocates of individual freedom, including Randal O'Toole, cited above, are hailing the autonomous vehicle revolution as another great step forward because it is claimed to solve the problems of congestion and road safety:

Pretty soon you will be able to drive a car - buy a car that will drive itself everywhere and they won't even have steering wheels. [...] if we can use the existing infrastructure, our four million miles of [US] roads and streets that we already have without any 
changes to them, self-driving cars can totally transform how we use that, make it a lot more effective, faster, cheaper, safer and more convenient than the transportation system we have today. (O'Toole 2019)

There is some scope and reason to disagree. While there are a hundred different views on the Autonomous Vehicle (AV) revolution, no-one really knows yet what to expect. The recent book by transport industry expert Sam Schwartz (No One at the Wheel: Driverless Cars and the Road of the Future, November 2018) amply demonstrates this, by quoting a dozen different conflicting sources and citing five mutually contradictory yet still plausible scenarios.

In the US at least, Elaine Chao, the Trump administration's Secretary of Transportation at the time of writing, is trying to mollify the libertarian supporters of the regime by promising that Americans will always have the joys of driving their cars on their beloved 'Open Road' even when AVs have taken over. The National Highway Traffic Safety Administration (NHTSA), an executive agency of the Department of Transportation (DoT) published its policy document 'Preparing for the Future of Transportation: Automated Vehicles 3.0', on October 4, 2018, wherein the last of the six stated U.S. DoT 'Automation Principles' reads as follows:

We will protect and enhance the freedoms enjoyed by Americans. U.S. DOT embraces the freedom of the open road, which includes the freedom for Americans to drive their own vehicles. We envision an environment in which automated vehicles operate alongside conventional, manually-driven vehicles and other road users. We will protect the ability of consumers to make the mobility choices that best suit their needs. We will support automation technologies that enhance individual freedom by expanding access to safe and independent mobility to people with disabilities and older Americans.

Until the Autonomous Driving Systems (ADS) revolution actually happens, no-one can tell whether this grand promise will ever be kept. But where the typically mendacious political rhetoric of a chaotic administration is concerned, it would no doubt be prudent to maintain a strict policy of caveat emptor. There is one scenario that is often invoked, and which is at least as plausible as any of the others: that human drivers in nonautomated vehicles will sooner or later be banned entirely from using the roads, and where is the 'enhanced individual freedom' then?

Why should the rest of the world worry about the US federal government's ADS policy and whether it will ever be implemented? Because whatever else may be said about it, the US is still a very influential country: where the US leads, many will follow.

\section{Conclusions}

Staggering and incalculable amounts of money are spent every year on paying people to jet around the planet and congregate in lavish hotels and conference centers to talk and think about ways to save lives on the world's roads, but the upward spiral of deaths and injuries continues unabated. Little or nothing has been achieved, and this seems unlikely to change. This paper has argued that all or most of that expenditure is wasted and all (or most of) those efforts are in vain because those experts and officials in their costly global get-togethers are all missing the point.

As long as the citizens of the world have any liberty left, they will in some degree be free to go astray and kill or maim themselves or others. Road traffic and motor vehicles are merely the modern mode of expression of the ancient two-edged sword called 'human freedom'. To err is human, as the old proverb goes, and if all chance of human error is one day eliminated, so is our fundamental humanity.

Until the day comes when we have handed over all agency and responsibility to the Ultimate Great Other of technology and are all riding around in 'autonomous vehicles' that make all the decisions for us - in other words, until we become totally enslaved to a machine intelligence that is not our own - there will continue to be car crashes, fatalities and injuries. Those who love liberty must be prepared to take that on board. This paper thus concludes, as befits its topic, with an open question: given what is well known about the history of the human mind, even if it were possible to 'reprogram' our DNA so as to eliminate from the world all forms of error, waste and loss, would we really want such a world?

\section{References}

1. Australasian College of Road Safety. 2019. "Full brochure on the College". Accessed 22 August 2019. https://acrs.org.au/wp-content/uploads/ACRS-DLBroch08.pdf

2. Australian Federal Government Transport and Infrastructure Council. 2019. "National Road Safety Strategy". Accessed 22 August 2019. https://www.roadsafety.gov.au

3. Fack, Dietmar. 2000. Automobil, Verkehr und Erziehung. Motorisierung und Sozialisation zwischen 
Beschleunigung und Anpassung 1885-1945. Opladen: Leske + Budrich.

4. FIA Foundation. 2019. "Road safety initiatives". Accessed 22 August 2019.

https://www.fiafoundation.org/our-work/road-safety

5. Freedom House. 2019. "Freedom in the World 2019". Accessed 22 August 2019.

https://freedomhouse.org/report/freedom-world/freedomworld-2019

6. Freud, Sigmund. 2005 [original German text 1930]. Civilization and Its Discontents (The Standard Edition) (Complete Psychological Works of Sigmund Freud). New York, NY: W. W. Norton.

7. Government of France. 2019. "Les grandes dates de la Sécurité routière". Accessed 22 August 2019.

https://www.securite-routiere.gouv.fr/mieux-nous-

connaitre/qui-sommes-nous/les-grandes-dates-de-lasecurite-routiere

8. GOV.UK. 2018. "Vehicle licensing statistics: January to March 2018". Accessed 22 August 2019.

https://www.gov.uk/government/statistics/vehicle-

licensing-statistics-january-to-march-2018

9. Nantulya V.M., Reich M.R. 2002. "The neglected epidemic: road traffic injuries in developing countries". British Medical Journal. 324(7346):1139-41.

10. National Highway Traffic Safety Administration (NHTSA). 2018. "Preparing for the Future of Transportation: Automated Vehicle 3.0". Accessed 22 August 2019.

https://www.transportation.gov/av/3

11. Narveson, J. 1988. The Libertarian Idea. Philadelphia: Temple University Press.

12. Niemann, Harry; Hermann, Armin (Eds.). 2006. Geschichte der Straßenverkehrssicherheit im Wechselspiel zwischen Fahrzeug, Fahrbahn und Mensch (Wissenschaftliche Schriftenreihe des DaimlerChrysler Konzernarchivs). Königswinter [Nordrhein-Westfalen]: Verlag Heel.

13. O'Toole, Randal. 2019. "Transportation, Land Use, and Freedom". Accessed 22 August 2019.

https://www.libertarianism.org/media/free-

thoughts/transportation-land-use-freedom

14. Schwartz, Samuel I. 2018. No One at the Wheel: Driverless Cars and the Road of the Future. New York, NY: PublicAffairs.

15. United Nations. 2015. "Sustainable Development Goals." Accessed 22 August 2019. https://www.un.org/sustainabledevelopment/sustainabledevelopment-goals/.
16. United Nations Road Safety Collaboration (UNRSC). 2019. "Decade of Action for Road Safety 2011-2020". Accessed 22 August 2019.

https://www.who.int/roadsafety/decade_of_action/en/

17. World Bank Data Team. 2019. "New country classifications by income level: 2018-2019". Accessed 22 August 2019.

https://blogs.worldbank.org/opendata/new-country-

classifications-income-level-2018-2019

18. World Health Organization [WHO]. 2010. "Decade of Action for Road Safety 2011-2020". Accessed 22 August 2019.

https://www.who.int/roadsafety/decade_of_action/en/

19. World Health Organization [WHO]. 2018a. "Global status report on road safety 2018." Accessed 22 August 2019.

https://www.who.int/violence_injury_prevention/road_safe ty_status/2018/en/

20. World Health Organization [WHO]. 2018b. "Road Safety Factsheet." Accessed 22 August 2019. https://www.who.int/news-room/facts-inpictures/detail/road-safety 